\title{
Akut ST Yüksekliği Olmayan Miyokard İnfarktüsü Tanısında Erken Diyagnostik Belirteç Olarak Kalp Tipi Yağ Asidi Bağlayıcı Protein'in Kalitatif Ölçümünün, Diğer Kardiyak Belirteçler Ille Karșılaștırılması
}

\author{
Comparison of Qualitati ve Measurement of Heart Type Fatty Acid Binding Protein With Other Cardiac \\ Markers as an Early Diagnostic Marker in Diagnosis of Non St Segment Elevation Myocardial Infartion
}

Demet Menekșe Gerede1, Sadi Güleç1, Veysel Kutay Vurgun1, Özgür Ulaș Özcan1, Hüseyin Göksülük', Mustafa Kılıçkap ${ }^{1}$,Çetin Erol ${ }^{1}$

\begin{abstract}
Amaç: Kalp tipi serbest yağ asidi bağlayıcı protein (H-FABP), akut miyokardinfarktüsünün (MI) erken dönem (ilk iki saat) tanısında kullanılan ve miyosit hasarını gösteren yeni bir kardiyak belirteçdir. Çalıșmamızda yatak bașı kalitatif H-FABP ölçümünün, ST yükselmesiz MI (NSTEMI)'nü erken tanıma ve dıșlama kabiliyetini belirlemek için rutinde kullanılan CK-MB kütle ve troponin I ile karșılaștırılması amaçlanmıștır.

Gereç ve yöntem: Çalıșmaya 30 dakikadan fazla süren iskemik tipte göğüs ağrısı yakınmasıyla ilk 12 saat içinde acil servise bașvuran ve elektrokardiyografi (EKG)'de ST yüksekliği bulunmayan 48 hasta alınmıștır. 24 saatlik takip sonucunda bu hastaların 24'ünde NSTEMI tanısı kesinleșmiș, kalan 24 hastada ise MI gelișmemiștir.

Bulgular: Hastaneye bașvuru saatlerine göre değișik altgruplar incelendiğinde H-FABP'nin erken tanıda ( $\leq 6$ saat) yüksek sensitivite $(\% 79)$ ve spesifisite $(\% 93)$ ile CK-MB ve troponine kıyasla daha iy bir diyagnostik belirteç olduğu (geçerlilik indeksi \%85) tesbit edilmiștir $(p<0,05)$.

Sonuç: H-FABP'ininfarkt sonrası erken yükselmesi, ölçümünün kolay olması ve hızlı sonuç vermesi gibi nedenlerle acil servislerde yatak bașı kullanımının doğru ve erken tanıda katkı sağlayacağ düșünülebilir.

Anahtar Sözcükler: Akut Koroner Sendrom, ST YükselmesizMiyokardlinfaktüsü, H-FABP, CK-MB, Troponin

Objective: Heart type fatty acid binding protein (H-FABP) is a new cardiac marker which is used in early diagosis (within the first two hours) of acute myocardial infarction (MI) and which shows myocyte injury. In our study, it was aimed to compare bed-side H-FABP measurement with routinely used CK-MB and troponin I for early diagnosis of non ST elevation MI (NSTEMI) and for determining its exclusion capacity.

Material and Method: A total of 48 patients who were admitted to emergency room with ischemic type chest pain lasting for more than 30 minute within the first 12 hours and who did not have ST segment elevation on electrocardigraphy (ECG) were included in the study. Definite diagnosis of NSTEMI was made in 24 patients as the result of 24-hour follow up, remaining 24 patients did not develop MI.

Results: When various subgroups were analysed according to admission hours, H-FABP was detected to be a beter diagnostic marker (accuracy $85 \%$ ) comparedto CK-MB and troponin with high sensitivity $(79 \%)$ and specifity $(93 \%)$ in early diagnosis $(\leq 6$ hours) $(p<0,05)$.

Conclusion: Bed-side H-FABP measurement may be considered to contribute to correct and early diagnosis as it elevated early following $\mathrm{Ml}$, its measurement is easy and it provides a rapid result.

Key Words: Acute Coronary syndrome, Non ST Elevation Myocardial Infarction, H-FABP, CK-MB, troponin.
\end{abstract}

Akut koroner sendrom (AKS) tanım itibariyle, koroner arter kan akımının ani olarak azalması sonucu gelişen miyokardial iskeminin neden olduğu klinik tabloların tamamını ifade etmektedir. Kararsiz anginapektoris
(UAP), ST segment yüksekliği ile birlikte görülen akut miyokard infarktüsü (STEMI) ve ST segment yüksekliği olmayan akut miyokardinfarktüsü (NSTEMI) bu klinik spektrumun farklı uçlarını 
olușturmaktadır. $\quad \mathrm{Bu} \quad$ klinik sendromların tamaminda hizlica tanı konulmalı ve tedavi edilmelidir $(1,2)$.

Göğüs ağrıs1, acil servise başvuru semptomlarının \%50'sini oluşturur ve bu hastaların yaklaşı $\% 25$ 'i yatırılarak izlenmektedir (3). AKS'lu hastalar da sıklıkla göğüs ağrisı yakınması ile başvurmaktadır. Yapılan çalışmalarda acil servise göğüs ağrisı ile başvuran hastaların nihai tanilarina bakıldığında, 1/3 kadarının akut miyokardinfarktüsü (AMI), 1/3'ünün kararsiz angina pektoris (UAP), $1 / 3$ ünün ise non-kardiak göğüs ağr1s1 olduğu saptanmıştır $(4,5)$.

AKS'lu hastaların 1/3'ünde ise klinik semptom yoktur. Elektrokardiyografi (EKG), AKS'un tespitinde değerli ve en sik başvurulan testtir. Bununla birlikte AKS'lu hastalarin ancak \%50'sinin ilk EKG'leri tanısaldır. O nedenle teşhis için seri EKG çekimleri yapılmalı ve EKG'lerde gözlenen değişiklikler sistematik olarak incelenmelidir. Önceki çalışmalara göre, AMI'lü hastaların \%2-10’u doğru tanı konulamaması nedeniyle acil servisden taburcu edilmektedir (6). Tanıdaki yetersizlik ve gecikme, uygun olmayan tedavilerin yapılmasına ve yaşamı kurtarabilecek tedavilerin başlanmasında gecikmeye neden olabilir.

Kardiyak hasar için daha duyarlilık ve özgüllük olan belirteçlerin (kardiyak troponinler, CK-MB kütle gibi) kullanıma girmesi ve bu belirteçlerin tanısal ve prognostik önemlerinin daha iyi anlaşılması ile AMI tanisindaki kriterler yeniden düzenlenmiştir. EuropeanSociety of Cardiology (ESC)/AmericanCollege of Cardiology (ACC) komitesi'nin 2000 yllında yayınladığ1 raporda, MI'nün tanisinda olmazsa olmaz kriter, kardiyak belirteçlerde yükseklik olarak tanımlanmıştır (7).

H-FABP, son zamanlarda keşfedilmiş olan bir kardiak belirteçtir. Kardiyomyositlerespesifik, düşük molekül ağırlıklı, sitosolik bir proteindir. Yağ asitlerinin mitokondrideki B-oksidasyonu için intrasellüler transportta önemli rol oynamaktadır $(8,9)$.

H-FABP akut miyokardiyaliskemi sırasındaki sarkolemmal değişiklikleri yansitır. Plasma kinetikleri ve sekresyonu, miyoglobin ile benzerdir. $\mathrm{Bu}$ nedenle AMI'nün erken tanısında (ilk iki saat) bir belirteç olarak değerlendirilir (10). H-FABP'nin AKS tanısında kullanımı ve değeri ile ilgili yapılmış az sayıda çalışma bulunmaktadır.

Miyokard dokusunda fazla bulunmas1, intra-sitosolikhakimiyeti, göreceli doku spesifisitesi, AMI sonrası kanda ve idrarda erken yükselmesi gibi özellikleri H-FABP'ninAKS'un erken tanısında kullanılabileceğini düşündürmektedir $(11,12)$.

Biz bu çalışmada, H-FABP'nin ANSTEMI'nün erken tanısında tanısal etkinliğini, diğer kardiyak belirteçler olan CK-MB ve Tn I ile kıyaslamayı amaçladık.

\section{GEREÇ VE YÖNTEM}

\section{Hasta seçimi}

Çalışmaya, Ankara Üniversitesi Tıp Fakültesi İbn-i Sina Hastanesi Acil Servis'ine 30 dakikadan uzun süren iskemik tipte göğüs ağrısı ile başvuran hastalar alındı.

Her hastanin detaylı olarak hikayesi alınıp, fizik muayenesi yapıldı. On iki derivasyonlu EKG'leri çekilerek, değişiklikler kaydedildi. EKG'de ST yüksekliği veya yeni gelişen sol dal bloğu olan hastalar, göğüs ağrisını takiben 12 saatten sonra başvuranlar, kronik böbrek yetmezliği olan hastalar, kronik kas hastalığ1 olanlar, yakın zamanda travma veya iskelet kası yaralanması geçirmiş hastalar, kalp yetersizliği olanlar ve şok tablosu ile gelenler çalışmaya dahil edilmedi.

Sonuçta kriterlere uyan ve NSTEMI olabileceği düşünülen 48 hasta çalışmaya alındı. Hastalardan tam kan, biyokimya ve acil kardiyak profil (CK-MB kütle ve Tn I) çalışılmak üzere kan alındı. Aynı zamanda alınan kandan yatak başı H-FABP çalışıldı.
Hastalar 24 saat süre ile gözlem altında tutuldu. Gözlem süresince 6 saat aralıklarla acil kardiyak profil ve EKG takibi yapild.

\section{Laboratuvar analizi}

Acil kardiyak profil çalışılmak üzere alınan kan örnekleri, bekletilmeden hastanemiz biyokimya laboratuvarına gönderildi. Beş cc düz tüpe alınan kan laboratuvarda 3000 devirde 10 dakika santrifüj edilip, serum kısmı ayrild1 ve Beckmen Coulter Access II cihazına yüklenerek, chemiluminescence yöntemi ile çalışıldı.

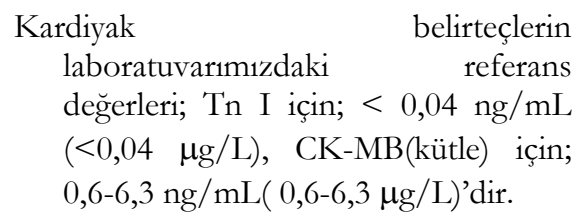

\section{H-FABP ölçümü}

Hasta çalışmaya alındıktan sonra yatak başı parmak ucundan damlatılan 3-4 damla kan, H-FABP kalitatif ölçüm (CardioDetect; Med-Rennessens, Niemcy, Poland) kit'ine damlatıldı. Kit 15 dakika süre ile düz bir zeminde bekletildi. İki çizgi görülmesi pozitiflik, tek kontrol çizgisi negatiflik, tek H-FABP çizgisi veya hiç çizgi görülmemesi ise yetersiz materyal olarak değerlendirildi. Bu testte $7 \mu \mathrm{g} / \mathrm{L}$ üzeri H-FABP miktarı pozitif olarak sonuç vermektedir (13). Kit sayıs1 sinırlı olduğundan her hastadan sadece başvuru sırasında bir kez H-FABP bakıldı.

\section{NSTEMI tanısI}

ESC/ACC tarafından önerildiği şekilde, $>30$ dkiskemik tipte gögüs ağrısına eşlik eden CKMB \pm Troponin I yüksekliği (en az iki farklı ölçümle doğrulanmış olmak kaydıyla) EKG değişikliği olsun olmasin NSTEMI olarak kabul edildi (7). 


\section{Istatistiksel analiz}

Çalışmadan elde edilen tüm veriler SPSS 10.0 istatistik programına aktarıldı. Grupların karşılaştırılmasında parametrik varsayımların gerçekleştiği durumda student's $t$ testi, parametrik varsayımların gerçekleşmediği durumda Mann-Whitney U testi, kategorik verilerin karşılaştırılması ve ilişskilendirilmesinde Chi-Square testi ve Fisher'sexact testi kullanildı. Ayrıca tarama testi sonuçları da verildi. $\mathrm{p}<0.05$ ise sonuç istatiksel olarak anlamlı kabul edildi. NSTEMI tanısında kardiyak belirteçlerin diyagnostik performansinı değerlendirmek için, başvuru zamanlarına göre her bir belirtecin duyarlılık, özgüllük, negatif prediktif değeri (NPD), pozitif prediktif değeri (PPD) ve geçerlilik (doğrulukkesinlik) indeksi (GI) hesaplandi. Tanisal Duyarhlik; NSTEMI tanisı alan ve belirteç pozitif olan hastaların, toplam NSTEMI tanısı almıs hastalara bölünmesi,
Tanısal Özgüllïk NSTEMI tanısı almayan ve belirteç negatif olan hastaların, NSTEMI tanisı almayan hastalara bölünmesi, NPD; NSTEMI tanıs1 almamış ve belirteç negatif olan hastaların, belirteç negatif olan tüm hastalara bölünmesi, PPD; NSTEMI olan ve belirteç pozitif olan hastaların, belirteç pozitif olan tüm hastalara bölünmesi sonucu elde edildi. Gi; NSTEMI ve belirteç pozitif olan hastalarla, NSTEMI olmayan ve belirteç negatif olan hastalarıntoplamının, toplam hastaya bölünmesi ile hesapland. Gİ, bir kardiyak belirteçin MI tanısında kabul edilebilir bir diyagnostik belirteç olabilme kriterini göstermektedir.

\section{BULGULAR}

Çalışmaya toplam 48 hasta alındı. Bu hastaların demografik ve klinik özellikleri Tablo 1'de verilmiștir. Hastaların semptom başlangıcından sonra hastaneye bașvuru saati ortalama 5.2 (2-10 saat) idi. Başvuru EKG'sinde hastaların 14'ünde (\%29)
ST depresyonu, 20'sinde (\%42) T negatifliği görülürken, 14'ünde (\%29) ise ST-T değişikliği saptanmadi. 24 saatlik takip sonucunda, 48 hastanın 24'üne NSTEMI tanis1 konuldu. Koroner anjiyografi işlemi 48 hastanın 40'ina yapıldı

NSTEMI tanısı kesinleșen bu 24 hastadan 20'sinde başvuru sırasında (göğüs ağris1 sonras1 2-10 saat) bakilan H-FABP pozitif iken, 4 hastada negatif sonuç elde edildi. $\mathrm{Bu}$ 4 hasta yanlıș negatif hasta grubunu oluşturdu. NSTEMI ekarte edilen 24 hastanin ise 22'sinde H-FABP negatif, 2'sinde pozitif bulundu. Bu 2 hasta yanlıs pozitif hasta grubu olarak değerlendirildi. Tablo 2'de nihai tanı olarak NSTEMI tanisi alan ve almayan hastalarda, bașvuru sırasında bakılan kardiyak belirteçlerin pozitif veya negatif olma durumu özetlenmektedir

Tablo 1. Hasta özellikleri

\begin{tabular}{|c|c|}
\hline Özellik & $\begin{array}{c}\text { Sayı (\%) veya ortalama } \pm \text { SD } \\
\text { (minimum-maksimum değerleri) }\end{array}$ \\
\hline Yaș & $60 \pm 9(38-79)$ \\
\hline Erkek cinsiyet & $28(\% 58)$ \\
\hline Hipertansiyon & $35(\% 73)$ \\
\hline Diabetesmellitus & $14(\% 29)$ \\
\hline Sigara & $23(\% 48)$ \\
\hline Total kolesterol, mg/dl & $204 \pm 57(97-311)$ \\
\hline $\mathrm{LDL}, \mathrm{mg} / \mathrm{dl}$ & $124 \pm 55(34-243)$ \\
\hline $\mathrm{HDL}, \mathrm{mg} / \mathrm{dl}$ & $45 \pm 11(14-69)$ \\
\hline Trigliserid, mg/dl & $148 \pm 88(19-533)$ \\
\hline Aile öyküsü & $12(\% 25)$ \\
\hline KAH öyküsü & $15(\% 31)$ \\
\hline Ağrı bașvuru zamanı, saat & $5,2 \pm 2,4(2-10)$ \\
\hline \multicolumn{2}{|l|}{ Bașvuru EKG'si } \\
\hline Tnegatifliği & $20(\% 42)$ \\
\hline EKG değișikliği olmayan & $14(\% 29)$ \\
\hline \multicolumn{2}{|l|}{ Koroner anjiyografi bulguları } \\
\hline Normal koronerler & $7(\% 17.5)$ \\
\hline Önemsiz darlık (<\%50) & $9(\% 22.5)$ \\
\hline Tek damar hastalığı & $13(\% 32.5)$ \\
\hline Çok damar hastalığı & $11(\% 27.5)$ \\
\hline
\end{tabular}

Tablo 2. NSTEMI tanısı alan ve almayan hastalarda başvuru sırasındaki kardiyak belirteçler

\begin{tabular}{|l|c|c|}
\hline & NSTEMI var $(\mathrm{n}=24)$ & NSTEMI yok $(\mathrm{n}=24)$ \\
\hline H-FABP pozitif, $\mathrm{n}(\%)$ & $20(83,3)$ & $2(8,3)$ \\
\hline Troponin I pozitif, $\mathrm{n}(\%)$ & $15(62,5)$ & $4(16,6)$ \\
\hline CK-MB pozitif, $\mathrm{n}(\%)$ & $12(50)$ & $1(4,1)$ \\
\hline
\end{tabular}


$\mathrm{Bu}$ verilerden yapılan analizler sonucunda

NSTEMI teşhisinde H-FABP için

Tanısal duyarlılık \%83,3, özgüllük

\%91,7, NPD \%84,6, PPD \%90,6, GI

$\% 87$ olarak bulunmuștur. $\mathrm{Bu}$

değerlerin diğer kardiyak belirteçlerle karşılaştırması $\quad$ Tablo 3'de

Özetlenmiştir.

Hastalar, ağrının başlangıcından sonra acil servise başvuru sürelerine göre

$\leq 3$ saat, 3-6 saat ve $>6$ saat olmak üzere 3 gruba ve $\leq 6$ saat, $>6$ saat olarak 2 gruba ayrıldığında elde edilen değerlerin karşılaştırmalı analizi ise Tablo 4 ve 5 'de verilmiștir.

Tablo 3. H-FABP, Tn I ve CK-MB'nin NSTEMI tanısında duyarlılık, özgüllük, NPD, PPD ve Gi'leri

\begin{tabular}{|l|c|c|c|c|}
\hline & Duyarlılık & Özgüllük & NPD & PPD \\
\hline H-FABP & $\% 83,3$ & $\% 91,7$ & $\% 84,6$ & $\% 90,9$ \\
\hline Tn I & $\% 62,5$ & $\% 83,3$ & $\% 68,9$ & $\% 78,9$ \\
\hline CK-MB & $\% 50$ & $\% 95,8$ & $\% 65,7$ & $\% 92,9$ \\
\hline
\end{tabular}

Tablo 4. Semptomların başlangıç saatine göre( $\leq 3,3-6$ ve $>6$ saat) NSTEMI tanısında, H-FABP, Tn I ve CK-MB'nin diyagnostik değerleri

\begin{tabular}{|c|c|c|c|}
\hline & $\leq 3$ saat $(n=15)$ & $3-6$ saat $(n=19)$ & $>6$ saat $(n=14)$ \\
\hline \multicolumn{4}{|l|}{$H-F A B P$} \\
\hline Duyarlılık & $\% 89$ & $\% 70$ & $\% 100$ \\
\hline Özgüllük & $\% 100$ & $\% 89$ & $\% 89$ \\
\hline NPD & $\% 86$ & $\% 73$ & $\% 100$ \\
\hline PPD & $\% 100$ & $\% 88$ & $\% 83$ \\
\hline $\mathrm{Gi}$ & $\% 93$ & $\% 78$ & $\% 92$ \\
\hline \multicolumn{4}{|l|}{ Troponin I } \\
\hline Sensitivite & $\% 33$ & $\% 70$ & $\% 100$ \\
\hline Spesifisite & $\% 100$ & $\% 67$ & $\% 89$ \\
\hline NPD & $\% 50$ & $\% 67$ & $\% 100$ \\
\hline PPD & $\% 100$ & $\% 70$ & $\% 83$ \\
\hline Gi & $\% 60$ & $\% 68$ & $\% 92$ \\
\hline \multicolumn{4}{|c|}{ CK-MB küt/e } \\
\hline Duyarlılık & $\% 22$ & $\% 50$ & $\% 100$ \\
\hline Özgüllük & $\% 100$ & $\% 89$ & $\% 100$ \\
\hline PPD & $\% 100$ & $\% 83$ & $\% 100$ \\
\hline $\mathrm{Gi}$ & $\% 53$ & $\% 68$ & $\% 100$ \\
\hline
\end{tabular}

Tablo 5. Semptomların başlangıç saatine göre (<=6 ve >6 saat) NSTEMI tanısında H-FABP, Tn I ve CK-MB'nin diyagnostik değerleri

\begin{tabular}{|c|c|c|}
\hline & $\leq 6$ saat $(n=34)$ & $>6$ saat $(n=14)$ \\
\hline \multicolumn{3}{|l|}{$H-F A B P$} \\
\hline Duyarlılık & $\% 79$ & $\% 100$ \\
\hline Özgüllük & $\% 93$ & $\% 89$ \\
\hline PPD & $\% 94$ & $\% 83$ \\
\hline $\mathrm{Gi}$ & $\% 85$ & $\% 93$ \\
\hline \multicolumn{3}{|l|}{ Troponin I } \\
\hline Özgüllük & $\% 80$ & $\% 89$ \\
\hline NPD & $\% 57$ & $\% 100$ \\
\hline PPD & $\% 77$ & $\% 83$ \\
\hline $\mathrm{Gi}$ & $\% 65$ & $\% 93$ \\
\hline \multicolumn{3}{|c|}{$C K-M B$ kütle } \\
\hline Duyarlılık & $\% 37$ & $\% 100$ \\
\hline Özgüllük & $\% 93$ & $\% 100$ \\
\hline NPD & $\% 54$ & $\% 100$ \\
\hline Gi & $\% 62$ & $\% 100$ \\
\hline
\end{tabular}


H-FABP'nin NSTEMI tanısinda $\leq 3$ saat için duyarlılık \%89, özgüllük \%100; 3-6 saat için duyarlllık \%70, özgüllük $\% 89$, ve $>6$ saat için duyarlllık $\% 100$, özgüllük \%89 olarak hesaplanmıştır. $\leq 3$ saatte ve 3-6 saatteki GI'lerine bakılarak H-FABP, CK-MB ve Tn I karşılaştırıldığında H-FABP'nin daha iyi bir tanısal belirteç olduğu görülmüştür (sirasılyla $\mathrm{p}<0.01 \quad$ ve $\mathrm{p}<0.05)$.
Semptom sonrası başvuru saatleri $\leq 6$ saat ve $>6$ saat olarak ikiye ayrıldığ1 zaman yapılan değerlendirmede ise H-FABP'nin $\leq 6$ saat için diyagnostik duyarlilık \%79, özgüllük $\% 93 ;>6$ saat için duyarlılık \%100, özgüllük \%89 saptanmıştır. $\mathrm{Bu}$ değerler $\mathrm{H}$ FABP'nin $\leq 6$ saatte NSTEMI tanısında oldukça duyarlı ve özgü bir belirteç olduğunu göstermektedir $(\mathrm{GI}=\%$ 85). Geçerlilik indeksleri karşılaştırıldığında erken dönem $(\leq 6$ saat) için H-FABP hem TnI'den
$(\% 85$ vs $\% 65, \mathrm{p}<0.05)$ hem de CKMB'den $(\% 85$ vs $\% 62, \mathrm{p}<0.05)$ daha iyi bir diyagnostik belirteç olarak değerlendirilmiştir. 6 saatten sonra başvuran hasta grubunda $(n=14)$ ise diyagnostik açıdan H-FABP, Tn I ve CK-MB arasinda istatistiki olarak anlamlı fark bulunamamıştır ( $>0.05)$. Şekil 1 ve 2'de kardiyak belirteçlerin başvuru saatlerine göre sahip oldukları Gİ değerlerinin karşılaştırmalı değerlendirilmesi verilmiștir.

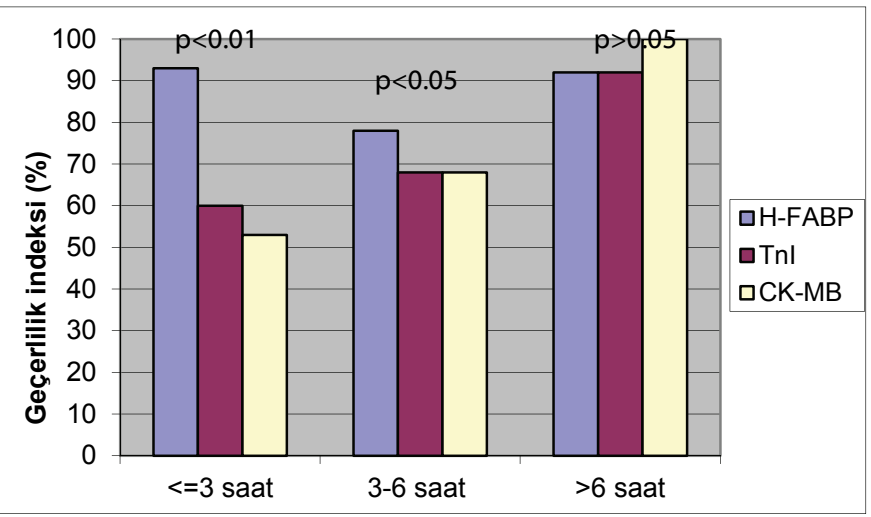

Şekil 1. Başvuru saatlerine göre $(\leq 3,3-6$ ve $>6$ saat) NSTEMI tanısında H-FABP, Tn I ve CK-MB'nin geçerlilik indeksler

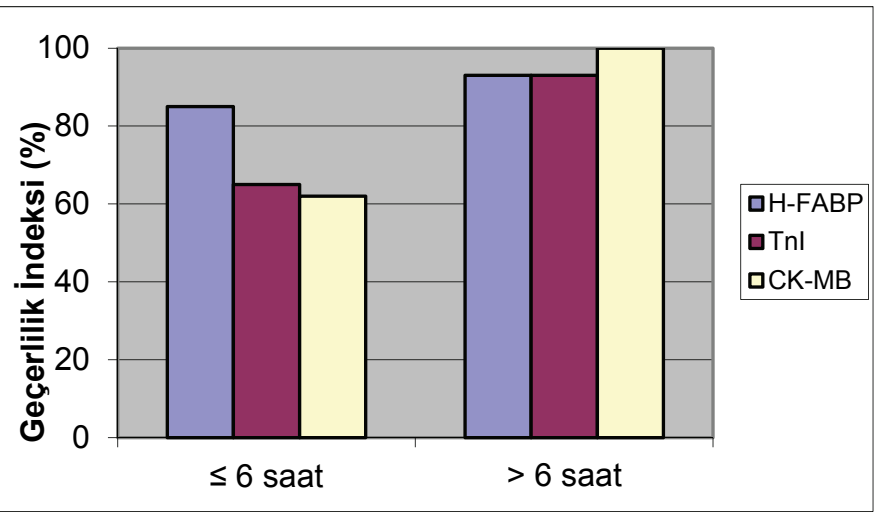

Şekil 2. Başvuru saatlerine göre ( $\leq 6$ saat ve $>6$ saat) NSTEMI tanısında H-FABP, Tn I ve CK-MB'nin geçerlilik indeksleri

\section{TARTIȘMA}

Çalıșmamızda, 30 dakikadan fazla süren iskemik tipte göğüs ağris1 yakınmasıyla ilk 12 saat içinde acil servise başvuran ve EKG'de ST elevasyonu bulunmayan 48 hastada, NSTEMI tanısında yatak başı HFABP ölçümünün rolü araştırılmıştır. Sonuç olarak, NSTEMI'nün erken tanisinda ( $\leq 6$ saat) H-FABP'nin yüksek sensitivite $(\% 79)$ ve spesifisite $(\% 93)$ ile (geçerlilik indeksi \%85), CK-MB ve troponine oranla daha iyi bir diyagnostik belirteç olduğu sonucuna varılmıstır.

Göğüs ağrısı ile acil servise başvuran bir hastada, ağrının özelliği iskemik ağriya benzese de benzemese de öncelikle hayatı tehdit edici bir durum olan AKS tanisinin ekarte edilmesi gereklidir. AKS tanısında EKG son derece önemli bir tanı yöntemi olmasına karşın, hastaların sadece \%50'sinde ilk çekilen EKG'nin diyagnostik olduğu bilinmektedir. Bu nedenle AKS tanısında göğüs ağrısı ve EKG dişında başka tanı yöntemlerine de gereksinim vardır. Kardiyak belirteçler, bu anlamda önemli bir rol üstlenirler. Öyle ki 2000 yilında ESC/ACC tarafindan AMI tanı kriterleri yeniden düzenlenmiş ve kardiyak belirteç (troponin $\pm \mathrm{CK}-\mathrm{MB}$ ) yüksekliği, tanı için olmazsa olmaz bir kriter olarak tanımlanmıştır. AMI'nü dışlamak için uygun zamanda kardiyak belirteçlere bakılmazsa tanı atlanarak, hastalar taburcu edilebilir. Önceki çalışmalara göre, AMI'lü hastaların \%2-10’u doğru tanı konulamaması nedeniyle acil servisden taburcu edilmektedir (6).

Öte yandan, yapılan çalışmalarda AMI şüphesi ile yoğun bakım ünitesinde izlenen hastaların, \%30'undan daha azında AMI olduğu saptanmıştır. Kardiak belirteçlere dayalı olarak yapilan hasta drenaj1, hastaların güvenliğini tehlikeye atmadan parasal harcamalarda da anlamlı bir azalma ile sonuçlanmaktadır (3).
AMI'nde tanının doğruluğu kadar erken teşhisi de önemlidir. Tanının erken konulmasiyla MI'ne daha erken müdahale ederek, hastanın prognozunu iyileştirme şansı yakalandığ1 gibi; MI olmadığının erken gösterilmesiyle de gereksiz ilaç kullanımı, gereksiz yatak işgali, gereksiz iş gücü kaybı ve gereksiz maddi kayıplar engellenerek, yoğun bakım ünitelerinde pahalı kaynakların verimli kullanımı sağlanabilecektir. Bu bağlamda MI sonrası kanda erken yükselen diyagnostik belirteçlere ihtiyaç duyulmaktadır $(1,3)$.

Geleneksel diyagnostik belirteçler ile (CK, CK-MB gibi) miyokard hasarının tespiti veya dışlanması ancak seri ölçümlerle saptanabilmektedir ve bu zaman kaybina neden olmaktadır. $\mathrm{Bu}$ nedenle AKS'u daha erken dönemde belirleme ve ekarte etme kabiliyeti göreceli olarak daha yüksek olan troponin ve miyoglobin gibi belirteçler kullanılmaya başlanmıştır. 
Yapılan çok sayıdaçalışmada, kardiyak troponinlerin AKS tanısinda, CK-MB ve miyoglobinden daha üstün olduğu gösterilmiştir. Bununla birlikte AKS’u düşündüren akut başlayan göğüs ağrisı ile gelen hastaların erken tanısı için kardiyak troponinlerin kullanıminda sinırlamalar mevcuttur. Akut iskemik olayı takiben ilk 6 saat içinde miyokardiyal hasarı saptamada, kardiyak troponinlerinsensitivitesi yeterli değildir. Ayrıca uzun süre plazmada yüksek olarak kaldığından ve yavaş seyirli bir azalma gösterdiğinden, akut iskemik olayın zamaninin saptanmasinda veya reinfarktüsün tayininde yetersiz kalmaktadır $(1,2)$.

Son zamanlarda H-FABP, AKS teşhisinde yeni bir kardiyak belirteç olarak tanımlanmıştır. Yapılan çalışmalarda erken diyagnostik ve prognostik bir belirteç olabileceği gösterilmiştir (14). AKS'un ilk semptomundan sonra yaklaşık olarak 1-3 saat içinde plazmada yükselmeye başlamakta ve 24 saat içinde plazmadan temizlenerek normal sinirlara inmektedir. H-FABP saptanmasinda birkaç immunokimyasal yöntem kullanilmakta olup, bu yöntemlerin süreleri 45 dakika ile 16 saat arasında değişmektedir. Yatak başı uygulanabilen ve kalitatif sonuç veren bu testle, süre 15 dakikaya inmektedir. $\mathrm{Bu}$ testte $>7 \mu \mathrm{g} / \mathrm{L} \mathrm{H}$ FABP miktarının bulunması pozitif olarak değerlendirilmektedir (13). Daha önce 38 hasta üzerinde yapilan bir çalışmada, H-FABP düzeyini kantitatif olarak saptamada kullanilan ve 45 dakikada sonuç veren ELISA yöntemi ile, kalitatif ölçüm yapan bu yatakbaşı yöntem kıyaslanmış ve her ikisinin tanı koydurmada benzer derecede başarılı olduğu gösterilmiştir (13,15). Literatürde yatak başı H-FABP ölçümünün AKS'dakidiyagnostik değeri ile ilgili daha önce yapılmış az sayıda çalışma mevcuttur $(16,17)$.

Glatz ve arkadaşlarının 1998'de 83 hasta üzerinde yaptıkları çalışmada, 6 saatin altında başvuran hastalarda $\mathrm{H}$ FABP'nindiyagnostiksensitivitesinin, miyoglobininsensitivitesinden daha iyi olduğu gösterilmiştir (\%78 vs $\% 53, \mathrm{p}<0,05)(18)$.

2000 yilında Haastrup ve arkadaşlarının ST uzun sürede elevasyonu olmayan ve 6 saatten gelen 130 hastada yaptıkları çalışmada, farklı referans değerleri için H-FABP sensitivitesi $\% 90-95$, spesifisitesi \%81-94 olarak saptanmıştır ve miyoglobin ile $\mathrm{H}$ FABP'in göğüs ağrısı olan hastaların erken triajında yararlı belirteçler oldukları belirtilmiştir (19).

Yoshihiko ve arkadaşlarının 129 AMI şüphesi olan hasta üzerinde yaptığ1 çalışmada ilk 3 saatte $\mathrm{H}$ FABP'ninsensitivitesi $\% 100$, spesifisitesi \%63 bulunmuştur. Aynı çalışmada Tn T'nin sensitivitesi $\% 50$, spesifisitesi $\% 96$ olarak tespit edilmiştir. İlk 3 saatte AMI tanısının konulmasinda H-FABP'nin'TnT'den daha geçerli bir belirteç olduğu sonucuna varmışlardır (20).

Rüzgar ve arkadaşlarının kalitatif $\mathrm{H}$ FABP ölçümü ile yaptığı çalışmada ilk 6 saatte H-FABP sensitivitesini \%95 olarak saptamışlardır, ancak bu çalışmaya ST yüksekliği olan göğüs ağrilı hastalar da alınmıştır (21). Biz çalışmamızda ST yüksekliği olan hastaları dahil etmedik, çünkü bu hastalarda zaten erken tanının göğüs ağrısına eşlik eden ST yüksekliği ile çoğu zaman kardiyak belirteç sonuçları beklenmeden konulabiliyor olmasindandir.

Çalışmamızda, <12 saat içinde gelen tüm hastalar ele alındığında H-FABP'nin tanısal duyarlılık, özgüllük, negatif ve pozitif prediktif değerleri sırasıyla $\% 83.3, \% 91.7, \quad \% 84.6$ ve $\% 90.6$ olarak hesaplanmıştır. Troponin ve CK-MB ile kiyaslandığında, HFABP'nin geçerlilik indeksi daha yüksek bulunduysa da, H-FABP'nin konvansiyonel belirteçlere net olarak üstünlük sağladığı esas zaman dilimi 6 saatten kisa sürede olmuștur. $\mathrm{Bu}$ dönemde H-FABP'nin geçerlilik indeksi \%85 iken, troponin ve CKMB'nin geçerlilik indeksleri bu değerin oldukça altında kalmıştır (sirasiyla $\% 65$ ve $\% 62, \mathrm{p}<0.05$ ).
Çalışmamızda H-FABP testi bakılan 4 hastada yanlış negatif, 2 hastada ise yanlış pozitif sonuç elde edilmiştir. Yanlış negatiflik ve yanlış pozitiflik için herhangi bir prediktör bulabilme umuduyla bu 6 hastanın tüm özellikleri detaylı olarak gözden geçirildiyse de, yanlış pozitiflik veya negatiflik durumunu izah edebilecek bir özellik tespit edilememiştir.

$\mathrm{Bu}$ çalışmanın literatürdeki çalışmalardan farklı noktaları, sadece uzun süreli iskemik tipte göğüs ağrısı olan hastaların alınması, ST yüksekliği olanların dışlanması ve ölçüm için yatak başı kalitatif yöntemin (CardioDetect) kullanılmış olması olarak özetlenebilir. Bizim çalışmamız bu konu hakkinda veri olması açısından önem taşımaktadır.

\section{Çalıșmanın kısıtıııkları}

Çalışmanın az sayıda hasta üzerinde yapılmış olması, tek merkezli olması, hastaların sadece uzun süreli iskemik tipte göğüs ağrisı olan hastalardan oluşması,H-FABP'nin her hastada sadece bir kez çalışılmış olması çalışmanın kısıtlılıkları olarak sayılabilir.

\section{SONUÇ}

Acil servise iskemik tipte göğüs ağrıs1 şikayeti ile gelen hastalarda, NSTEMI teşhisinde H-FABP iyi bir erken dönem diyagnostik belirteç olarak görünmektedir. 6 saatten kısa sürede başvuran hastalarda rutinde kullanılan diğer kardiyak belirteçlerolan TnI ve CK-MB (kütle) ile kıyaslandığında daha sensitif ve spesifik bir belirteç olan H-FABP'nininfarkt sonrasi erken yükselmesi, ölçümünün kolay olması ve hızlı sonuç vermesi gibi nedenlerle acil servislerde yatak başı kullanımının erken tanıda katkı sağlayacağı sonucuna varılmıştır. Bu uygulamaya rutin olarak başlanmadan önce sonuçlarımızın daha büyük ölçekli çalışmalarla doğrulanması gereklidir. 


\section{KAYNAKLAR}

1. Antman EM, Braunwald E. Acute myocardial infarction In: Braunwald E, Zipes D, Libby P, eds. Heart Disease. Ed: A textbook of cardiovascular medicine. Philadelphia: WB Saunders company 2001:1131-1135.

2. Newby LK, Gibler B, Chriztenson RH. Serum markers for diagnosis and risk stratification in acute coronary syndromes, ed; Cannon CP, Humana Pres, NJ, 1999:147- 171.

3. Hodgson L. Cost containment in the emergency department. CAL/ACEP source guide 1998; 710: 23.

4. Hargarten K, Chapman PD, Stueven $\mathrm{HA}$, et al. Prehospital prophylactic lidocaine does not favorably affect outcome in patients with chest pain. Ann Emerg Med 1990; 19: 12741279.

5. Reeder G. Contemporary diagnosis and management of unstable angina. Mayo Clinic Proceedings 2000; 75: 953-960.

6. Rusnack RA, Stair TO, Hansen K, et al. Litigation against the emergency physician: Common features in cases of missed myocardial infarction. Ann Emerg Med 1989; 18: 1029-1034.

7. Anon, Joint European Society of Cardiology / American College of Cardiology Committee. Myocardial infarction redefined: a consensus document of the Joint European Society of Cardiology / American College of Cardiology Committee for the redefinition of myocardial infarction. Eur Heart J 2000; 21: 1502-1513.

8. Schaap FG, Binas B, Danneberg H, et al. Impaired long-chain fatty acid utilization by cardiac myocytes isolated from mice lacking the hearttype fatty acid binding protein gene. Circ Res 1999; 85: 329-337.

9. Glatz JFC, van der Vusse GJ, Simoons ML et al. Fatty acid binding protein and the early detection of acute myocardial infarction. Clin Chim Acta 1998; 272: 87-92.

10. Van Nieuwenhoven FA, Kleine AH, Wodzig WH, et al. Discrimination between myocardial and skeletal muscle injury by assesment of the plasma ratio of myoglobin over fatty acid binding protein. Circulation 1995; 92: 2848-2854.

11. Yoshimoto K, Tanaka T, Somiya K, et al. Human heart-type cytoplasmic fatty acid-binding protein as an indicator of acute myocardial infarction. Heart Vessels 1995;10: 304-309.

12. Tanaka T, Hirota $Y$, Sohmiya $K$, et al. Serum and urinary human heart fatty acid-binding pro $\neg$ tein in acute myocardial infarction. Clin Biochem 199; 24:195-201.

13. Chan C, Sum KW, Cheeung KY, et al. Development of a quantitative lateralflow assay for rapid detection of fatty acid-binding protein. Journal of Immunological Methods 2003; 279: 91- 100.

14. Nakata T, Hashimoto A, Hase M, et al. Human Heart-Type fatty acidbinding protein as an early diagnostic and prognostic marker in acute coronary syndrome. Cardiology 2003; 99: 96-104.

15. Chan C, Wan T, Watkins $\mathrm{K}$, et al. Rapid analysis of fatty acid-binding üproteins with immunosensors and immunotests for early monitoring of tissue injury. Biosensors and Bioelectronics 2005;20: 2566-2580.

16. Zeren G, Erer HB, Kiris T, et al. ST segment yükselmesiz akut koroner sendromlu hastalarda kalp tipi yağ asidi bağlayıcı proteinin koroner arter hastalı̆̆ının yaygınlık ve ciddiyeti ile ilișkisi. Arch Turk Soc Cardiol 2013;41: 610-616

17. Freund $\mathrm{Y}$, Chenevier-Gobeaux $\mathrm{C}$, Leumani $F$, et al. Heart-type fatty acid binding protein and the diagnosis of acute coronary syndrome in the ED. Am Journal of Emergency Medicine 2012; 30:13781384.

18. Glatz JF, Vusse GJ, Simoons M, et al. Fatty acid-binding protein and early detection of myocardial infarction. Clinica Chimica Acta 1998; 272: 87 92.

19. Haastrup B, Gill S, Kristensen R, et al. Biochemical markers of ischaemia for the early identification of acute myocardial infarction without ST segment elevation. Cardiology 2000; 84: 254-261.

20. Yoshihiko S, Tomita Y, Tekano Te, et al. Office cardiologists cooperative study on whole blood rapid panel tests in patients with suspicious acute myocardial infarction. Circ J 2004; 68: 144-148.

21. Ruzgar O, Bilge AK, Bugra Z et al. The use of human heart-type fatty acidbinding protein as an early diagnostic biochemical marker of myocardial necrosis in patients with acute coro nary syndrome, and its comparison with troponin- $T$ and creatine kinase myocardial band. Heart and Vessels 2006;21: 309-314 
